JURNAL PIWULANG, Vol. I No. 1 September 2018, 1-18

\title{
Model Pendidikan Agama Anak bagi Wanita Karir Keluarga Muslim di Kota Malang
}

\author{
Oleh: \\ Mahrus \\ Dosen Tetap STAI NU Malang \\ Email:mahrus283@gmail.com
}

\begin{abstract}
Peran wanita sebagai Ibu rumah tangga ataupun wanita yang berkarir memiliki kewajiban yang sama untuk memberikan pendidikan agama bagi anak. Setiap Ibu memiliki tujuan pendidikan mewujudkan yang ingin diraih oleh anaknya agar dapat menjadi pribadi yang baik. Berangkat dari keinginan ini para ibu yang juga berkarir sebagai pegawai pabrik rokok, pegawai bank dan guru tersebut melakukan berbagai upaya untuk memberikan pendidikan agama bagi anaknya sebagai pengganti ketiadaannya selama berkarir melalui beberapa kegiatan seperti TPQ, dititipkan pada tetangga dan di masukkan ke lembaga pedidikan yang memberikan porsil lebih pada aspek keagamaan seperti Playgroup Qurrotun A'yun, TK Permata Iman, TK Insan Amanah, TK Muslimat, MIN 1 Malang dan lain sebagainya. Hasil yang didapat dari berbagai upaya tersebut adalah anak terbiasa melakukan sholat 5 waktu sejak kecil, bersopan santun pada orang tua, berperilaku baik kepada tetangga dan lain sebagainya.
\end{abstract}

Key words: Model Pendidikan Agama, Wanita Karir, Keluarga Muslim.

\section{A. Pendahuluan}

Dalam konteks Tri Pusat Pendidikan, peran orang tua dalam dunia pendidikan khususnya pendidikan anak ditempatkan pada urutan teratas mengungguli pendidikan formal di sekolah dan pendidikan non formal di masyarakat. Hal ini mengindikasikan bahwa orang tua memiliki peran yang amat besar dalam proses pendidikan anak.

Sebagai lembaga pendidikan pertama dalam mengawal pertumbuhan seorang anak, maka peran orang tua perlu diperhatikan dengan benar agar anak bisa tumbuh dengan sehat baik secara fisik maupun psikis. Sehat secara fisik berarti anak tumbuh secara normal dan bergerak aktif dalam masa perkembangan. Lebih lanjut, anak mengalami pertumbuhan fisik secara teratur dan sesuai dengan usianya yang tumbuh 
JURNAL PIWULANG, Vol. I No. 1 September 2018, 1-18

kembangnya tetap dalam pengawasan orang tua. Sedangkan sehat secara psikis ialah anak dapat tumbuh secara baik dari sisi mental dan kejiwaannya.

Ada seorang penyair berkata:

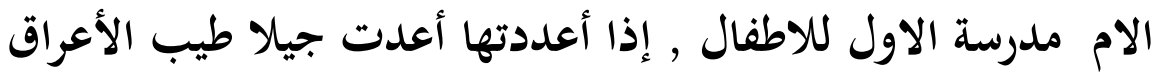

Artinya: "Ibu adalah madrasah pertama bagi anak, jika kamu menyiapkannya maka dia menyiapkan generasi yang berkarakter baik" (Ahmad Syauqi) $^{1}$

Syair di atas memberi sebuah makna bahwa seorang Ibu memiliki sebuah kewajiban dan tanggung jawab yang sama yaitu merawat, membesarkan dan mendidik putra-putrinya dengan baik. Kewajiban dan tanggung jawab ini berlaku pada semua wanita yang ada di dunia ini dimanapun ia berada dengan segala jenis latar belakang kehidupannya, jenjang pendidikan yang pernah ditempuh dan lain sebagainya.

Karena ibu adalah sekolah pertama maka dia dituntut memiliki kemampuan-kemampuan dasar agar mampu memerankan fungsinya secara positif dan berarti kepada anaknya. Di antara kemampuankemampuan tersebut adalah: (1). Kemampuan dasar agama khususnya yang berkaitan dengan ibadah-ibadah praktis sehari-hari; (2). Kemampuan dasar calistung (membaca, menulis dan berhitung) disertai pengetahuan tentang metode pengajarannya kepada anak; (3). Kemampuan dasar bermain yang edukatif karena dunia anak adalah dunia bermain dan tidak semua permainan memiliki nilai positif dan disinilah ibu yang memilah dan memilih jenis permainan yang baik buat anak; (4). Pengetahuan dasar-dasar akhlak yang baik dan metode penamaannya pada anak dan (5). Pengetahuan dasar tumbuh kembang anak dan faktor penunjanganya. Hal ini untuk mengoptimalkan pertumbuhan anak sehingga dia menjadi anak yang sehat karena kesehatan fisik menunjang perkembangan sisi-sisi anak yang lain.

\section{B. Konsep Dasar Pendidikan Islam Keluarga}

\section{Pendidikan Islam}

Pendidikan Agama Islam (PAI) merupakan usaha sadar dan terencana untuk menyiapkan siswa dalam meyakini, memahami, menghayati dan mengamalkan ajaran Islam melalui kegiatan bimbingan, pengajaran dan latihan.

Pendidikan agama Islam pada hakikatnya merupakan sebuah proses yang dalam pengembangannya juga dimaksud sebagai rumpun mata pelajaran yang diajarkan di sekolah maupun perguruan tinggi.

${ }^{1}$ www.najmulhayah's.blog.com, diakses pada tanggal 25-06-2017 pukul 10.00 WIB 
Dengan demikian, pendidikan Agama Islam dapat dimaknai dalam dua pengertian: (1) sebagai sebuah proses penanaman ajaran Islam, (2) ssebagai bahan kajian yang menjadi materi dari proses penanaman atau pendidikan itu sendiri. ${ }^{2}$

\section{Pendidikan Keluarga}

Keluarga merupakan basis segala segi yang berhubungan dengan pendidikan, baik pendidkan rohani, sosial, fisik dan mental. Keluarga itu bisa menentukan masa depan seorang anak. Disanalah ia memperoleh dasar-dasar hidup yang akan dikembangkan di sekolah dan di lingkungan pergaulan si anak dengan orang lain.

Secara sosiologis, Djuju Sudjana (1990) mengemukakan tujuh macam fungsi keluarga, yaitu: ${ }^{3}$ (1). Fungsi biologis; (2). Fungsi edukatif; (3). Fungsi religius; (4). Fungsi protektif; (5). Fungsi sosialisasi; (6). Fungsi rekreatif; dam (7). Fungsi ekonomis.

Dalam segi metode, ada beberapa metode penyampaian materi pendidikan bagi anak, seperti yang dikemukakan oleh Moh. Padil \& Triyo Supriyanto antara lain : Metode Pengganjaran dan Hukuman, Metode Directive Learning, dan Metode Pemberian Contoh ${ }^{4}$

\section{Tahapan-tahapan Pendidikan Anak}

Setidaknya ada 5 tahap pendidikan pada anak, yakni:

a) Mendidik Anak ketika dalam Kandungan. Terdapat beberapa aspek yang harus diperhatikan oleh orang tua atau calon orang tua. Aspek-aspek tersebut adalah Aspek Makanan dan Aspek Prilaku Orang Tua

b) Mendidik Anak Usia Balita. Pada usia dini, anak-anak 0 tahun, begitu ia dilahirkan maka anak bayi tersebut telah diberikan pendidikan agama dengan memperdengarkan kalimat thoyibah, serta memperdengarkan adzan di telinga kanan dan iqamat di telinga kiri untik anak laki-laki dan perempuan. Pendidikan agama ini dimulai dari rumah tangga dengan latihan dan keteladanan yang baik yang diberikan oleh orang tua secara terus menerus dan berkesinambungan sampai anak berumur 4 tahun yang dilanjutkan dengan membaca Al-Qur'an

Anak usia balita sudah harus diajarkan dengan beberapa kebiasaan dan perkataan yang baik. Mulai dari bersikap sopan santun dan bisa belajar kata-kata baik seperti terima kasih ketika

\footnotetext{
${ }^{2}$ Nazarudin, Manajemen Pembelajaran Implementasi Konsep, Karakteristik dan Metodologi Pendidikan Agama Islam di Sekolah Umum, (Yogyakarta: Teras, 2007), hlm. 24

3 Mufidah Ch, Paradigma Gender, (Malang: Bayumedia Publishing, 2003), hlm. 74-75

${ }^{4}$ Moh. Padil \& Triyo Supriyanto, Sosiologi Pendidikan, (Malang: UIN-Malang Press, 2007), hlm. 128-131
} 
JURNAL PIWULANG, Vol. I No. 1 September 2018, 1-18

berusia satu tahun. Mungkin mereka belum bisa mengucapkannya dengan sempurna, tapi itu merupakan pembelajaran yang amat penting.

Upaya mendidik anak usia balita (di bawah lima tahun) antara lain dapat kita lakukan sebagai berikut: ${ }^{5}$

- Tidak bersikap memanajakan anak secara berlebihan.

- Dalam hal mendiamkan anak yang sedang menangis, hendaknya dihindari cara menakut-nakuti.

- Dalam hal menyusui anak (khusus bagi Ibu) hendaknya diusahakan tidak melewati usia dua tahun.

- Saat anak kita mulai belajar bicara, ajarkanlah kata-kata pendek yang merupakan perkenalan dengan orang-orang terdekat dengan anak

- Saat menyuapi anak atau memberi makan anak, biasakan orang tua membaca doa dengan suara yang agak dikeraskan agar anak dapat mendengar dan diharapkan dia akan menirunya.

- Apabila anak kita sudah mulai belajar berjalan atau sudah bisa berjalan dan suatu saat mungkin terjatuh, maka ketika ia terjatuh tidak langsung ditolong.

- Dalam hal memberi barang mainan, hendaknya kita pilih yang dapat merangsang daya kreasi anak dan tidak membahayakan dirinya

- Anak kita perintah untuk dapat mengambil dan menaruh barang mainannya sendiri di tempatnya dengan maksud agar anak belajhar tidak selalu bergantung pada orang lain dan untuk melatih disiplin. ${ }^{6}$

- Kita menyuruh anak untuk mengantarkan makanan kepada tetangga atau memberi sesuatu kepada pengemis yang datang ke rumah yang mana hal ini dimaksudkan untuk mendidik kedermawanan dan rasa peduli terhadap sesama.

- Apabila hendak menidurkan anak, antarakan dia dengan dongeng atau cerita dan nyanyian yang religius (mempunyai nilai keagamaan)

- Menyiapkan alat tulis-menulis saat anak sudah mulai mau mencorat-coret.

- Kita ajari anak untuk memulai suatu pekerjaan dengan membaca doa.

${ }^{5}$ Moh. Padil \& Triyo Supriyanto, Sosiologi Pendidikan,... hlm. 34-37

${ }^{6}$ Moh. Padil \& Triyo Supriyanto, Sosiologi Pendidikan, hlm. 47 
JURNAL PIWULANG, Vol. I No. 1 September 2018, 1-18

- Menyediakan gambar-gambar yang dapat memancing perhatian anak sehingga ia akan bertanya. Ini dimaksudkan untuk melatih kecerdasan anak.

- Orang tua hendaknya menyediakan waktu-waktu khusus untuk bercengkerama, bercanda ria dengan anak secara lepas.

- Tidak memarahi apalagi membentak atau berkata kasar jika anak merusak sesuatu barang di rumah.

- Ada baiknya hari kelahiran anak diperingati dengan maksud mendidik anak untuk mensyukuri nikmat masih bisa hidup yang diberikan Tuhan.

- Orang tua harus menghindari dari berprilaku tidak baik di hadapan anak karena hal tersebut bisa ditiru/ dicontoh oleh anak

- Hindari memakai pakaian yang berlawanan dengan jenis kelamin anak.

- Biasakan anak dengan berbagai kegiatan yang sesuai dengan usia, pembawaan, jenis kelamin dan tingkat perkembangan anak.

- Pandai-pandailah orang tua mengamati pertumbuhan dan perkembangan anak.

- Dalam banyak hal orang tua harus mampu berperan sebagai guru yang patut digugu atau ditiru oleh anak-anaknya.

- Orang tua harus menjadi suri tauladan bagi anak-anaknya. Hal ini karena keteladanan dalam pendidikan merupakan bagian dari sejumlah metode paling ampu dan efektif dalam mempersiapkan dan membentuk anak secara moral, spiritual dan sosial. ${ }^{7}$

c) Mendidika Anak Usia TK

Prilaku pendidikan dari orang tua kepada anak yang berusia TK diantaranya: ${ }^{8}$

- Orang tua mulai menjelaskan kepada anak bahwa kini dia telah menjadi seoarang murid.

- Ketika anak harus sekolah, seyogyanya tidak selalu harus diantar, kecuali hari-hari pertama saja.

- Jika orang tua sempat mengantar jemput anak menggunakan kendaraan pribadi

- Orang tua harus dapat mengikuti perkembangan anak beserta hasil belajarnya.

${ }^{7}$ Abdullah Nashih Ulwan, Pendidikan Anak Menurut Islam Kaidah-Kaidah Dasar, (Bandung: PT Remaja Rosdakarya, 1992), hlm. 2

${ }^{8}$ Abdullah Nashih Ulwan, Pendidikan Anak Menurut Islam Kaidah-Kaidah Dasar, hlm... 38-42 
JURNAL PIWULANG, Vol. I No. 1 September 2018, 1-18

- Orang tua harus dapat memberikan pujian dan penghargaan terhadap prestasi belajar anak.

- Memberikan hadiah pada guru anak kita yang penyerahannya juga melalui anak kita dalam bentuk yang wajar agar timbul keakraban antara anak dengan gurunya.

- Jika anak mendapat tugas dari guru untuk dikerjakan di dalam rumah, orang tua tidak boleh mengambil alih tugas anak tersebut.

- Orang tua bertanya kepada anak tentang apa saja yang diajarkan oleh guru dan diminta untuk mengulanginya.

- Orang tua menyuruh anaknya untuk menyipkan atau mengemasi perlengkapan sekolahnya, menyimpan di tempat yang telah ditentukan. Namun, semua hal tadi hanya sebatas yang sudah bisa mereka kerjakan

- Orang tua tidak boleh melakukan hal yang berlawanan dengan apa yang dilakukan oleh guru anak kita.

- Dalam banyak hal, orang tua harus selalu mampu tampil sebagai guru atau pendidik bagi anak-anaknya dengan cara menyelaraskan peranan yang diambil dengan corak pendidkan yang diberikan oleh guru atau sekolah.

- Bagi anak yang disekolahkan di TK, maka seyogyanya orang tua memberikan pengajaran terhadap anak yang disesuaikan dengan pola pendidikan yang ada di sekolah taman kanakkanak.

- Saat kita melaksanakan tugas mengajar atau mendidik, hendaknya bisa memisahkan status diri kita sebagai orang tua yang identik dengan kekuasaan yang mutlak dengan diri kita yang sedang bertindak sebagai pendidik.

- Agar anak merasa tidak sendiri, maka ada baiknya dicarikan teman belajar yang seusianya yang juga bersekolah di TK

- Selaku orang tua tidak sepatutnya kita mengabaikan pendidikan bagi anak.

d) Mendidik Anak Usia SD

Beberapa tindakan yang seyogyanya dilakukan oleh para orang tua, yaitu: ${ }^{9}$

1) Anak diminta untuk semakin membiasakan diri melakukan halhal berikut:

- Memelihara, meniapkan, dan menggunakan sarana belajarnya dengan tertib

${ }^{9}$ Abdullah Nashih Ulwan, Pendidikan Anak Menurut Islam Kaidah-Kaidah Dasar..., hlm. 44-48 
JURNAL PIWULANG, Vol. I No. 1 September 2018, 1-18

- Mematuhi jadwal kapan ia harus belajara, bermain, tidur siang, tidur malam dan bangun pagi.

2) Terhadap tugas atau kewajiban di rumah, orang tua sebaiknya memberi jatah secara wajar, seperti berikut ini:

- Menyapu halaman, menyiram taman, memberi makan hewan peliharaan dan lain sebagainya

- Membeli keperluan dapur di warung yang dekat dengan rumah

3) Kepada anak mulai diberikan pengertian agar jika akan memasuki kamar orang tua harus memberikan isyarat atau meminta izin terlebih dahulu.

4) Orang tua tidak memperlihatkan "adegan romantis" di hadapan anak karena hal ini kemungkinan besar akan ditiru oleh anak.

5) Dalam hal yang berkaitan dengan keyakinan beragama, hendaknya orang tua melakukan hal-hal berikut ini:

- Mulai menyuruh anak untuk melaksanakan perintah agama

- Mengajak mereka untuk bersama-sama menjalankan perintah agama

- Menjelaskan arti penting dan manfaat beragama

6) Jangan mengajari anak untuk berdusta.

7) Orang tua harus menemani anak ketika dia sedang menonton televisi.

8) Yang menyangkut kamar atau tempat tidur, sebaiknya kita sebagai orang tua harus memberi jatah untuk anak kamar tidur yang terpisah.

9) Yang menyangkut hobi kita dalam menghias dinding atau memasang kalender diusahakan jangan sampai menampilkan benda-benda gambar-gambar yang tidak senonoh dan tidak pantas dilihat oleh anak karena hal seperti ini akan menimbulkan pengaruh negatif kepada anak meski gambargambat tersebut adalah benda mati.

10)Mengajak anak untuk bersilaturahmi atau berkunjung ke ruamah famili dan kerabat untuk mendidik anak akan pentingnya rasa kekeluargaan, keakraban dan kasih sayang.

11)Mengajak anak untuk berekreasi dalam rangka menyegarkan suasana batin anak dan juga memberi anak kesempatan untuk bermain serta menambah pengalaman bisa berdekatan dengan alam.

12)Mengajak anak untuk menjenguk kerabat atau temannya yang sedang sakit sebagai stimulasi positif bagi anak agar tetanam di dalam diri anak rasa peduli terhadap sesama.

13)Dalam hal rasa cinta kepada tanah air, bangsa dan negara pada diri anak kitam ada baiknyua jika sesekali mengajak anak untuk 
JURNAL PIWULANG, Vol. I No. 1 September 2018, 1-18

mengunjungi tempat-tempat bersejarah seperti museum, taman makam pahlawa dan lain sebagainya. ${ }^{10}$

e) Mendidik Anak Usia SLTP

Mendidik anak berusia SLTP sudah tentu berbeda dengan cara yang dilakukan ketika anak masih berusia SD. Hendaknya perlu kita ingat bahwa anak kita sekarang telah berusia 12-15 tahun dan telah duduk di dalam sekolah lanjutan tingkat pertama. Anak telah tumbuh menjadi seorang yang lebih besar dan beranjak remaja meski masih dalam kategori remaja kecil.

Cara mendidik anak yang berkenaan dengan hak anak pada usia SLTP. Namun, sebelum membicarakan tentang apa saja hak seorang anak pada usia SLTP, ada baknya kita memahami dulu arti dari hak. Hak adalah sesuatu yang harus diterima dari seseorang yang diperoleh dari orang lain.

f) Mendidik Anak Usia SLTA

Dari sekian tahapan mendidik anak, maka mendidik anak yang telah berusai SLTA merupakan bagian yang banyak sekali romantikanya.penuh dengan problematika yang menanti penangananyang serba tepat dan manusiawi. Betapa tidak, anak yang sudah seusia SLTA ini berada pada masa "transisi" atau peralihan. Masa ini juga sering disebut dengan masa puber. Anak pada masa ini tengah mengalami peralihan dari masa anak-anak ke masa dewasa. ${ }^{11}$

Berikut ini sebuah pembahasan untuk mengetahui tentang seluk beluk masa puber, yaitu:

- Masa puber dianggap sebagai proses sosialisasi dalam mencari identitas diri atau biasa disebut sebagai masa untuk menentukan diri. ${ }^{12}$

- Remaja puber seringkali melawan kekuasaan orang tua serta kurang bertanggung jawab dalam penggunaan waktu.

- Remaja puber seringkali memperlihatkan sikap yang lebih dewasa mengenai ciri dan lingkungannya.

- Remaja puber memuiliki perasaan yang labil antara kelebihan dan kekurangannya.

${ }^{10}$ Charles Schaefer, Bagaiman Mempengaruhi Anak Peganagan Praktis Bagi Orang Tua, (Semarang: Dahara Prize, 1989), hlm 61-62

11 Kartini Kartono, Psikologi Anak (Psikologi Perkembangan), (Bandung: Mandar Maju, 2007), hlm. 168

12 Pusat Pengembangan Penataran Guru Tertulis Ditjen Dikdasmen Depdikbud, Bimbingan dan Penyuluhan, (Bandung, 1982-1983), hlm. 47 
JURNAL PIWULANG, Vol. I No. 1 September 2018, 1-18

- Remaja puber ingin mencari kebebasan/ kemerdekaan, tetapi juga mengharapkan adanya rasa terjamin.

- Remaja puber ingin memperlihatkan "lambang-lambang" kedewasaan, seperti merokok, minum minuman keras dan lainlain.

- Remaja puber ingin menetapkan pembagian waktu menurut seleranya sendiri.

\section{Konsep Dasar Wanita Karir}

a) Identitas Wanita

Asal Usul penciptaan wanita atau biasa disebut perempuan tidak diceritakan secara kronologis dalam Al-Qur'an. Cerita tentang penciptaan perempuan banyak diketahui melalui hadits-hadits, kisah-kisah israiliyat dan riwayat-riwayat yang bersumber dari kitab Taurat (kitab suci agama Yahudi), Injil (kitab suci agama Kristen) dan cerita-cerita yang bersumber dari kitab Tamlud, kitab yang banyak memberikan penafsiran terhadap kitab Taurat.

Al-Qur'an memang tidak menyebutkan secara terperinci asal usul penciptaan perempuan. Yang ada hanya cerita tentang kesombongan Iblis yang berdampak pada Adam as. dan pasangannya (Hawa) sehingga keduanya harus meninggalkan Surga. ${ }^{13}$ Namun demikian, ada beberapa riwayat menceritakan asal usul kejadian perempuan yang redaksinya hampir sama dengan cerita yang ada dalam Kitab Kejadian, seperti disebutkan dalam tafsir ath-Thabari ${ }^{14}$. Secara fitrah, kodrat dan fungsi wanita jelas berbeda dengan laki-laki. Kodrat wanita berbeda dengan laki-laki dalam hal: ${ }^{15}$ haidh. hamil, melahirkan, dan menyusui.

b) Lahirnya Gerakan Emansipasi

Berbicara tentang ibu karir atau wanita karir mungkin tidak akan lepas dari konsep emansipasi wanita. Gerakan emansipasi secara terbuka dan terarah lahir pada awal abad XX. Propagandanis dari gerakan ini kebanyakan dari kaum laki-laki dan hanya sedikit saja dai kalangan wanita. Pada awalnya, gerakan eamnsipasi tampil dalam bentuk seruan tentang pentingnya pendidikan akademis bagi kaum wanita. Slogan maupun jargon politik yang dimunculkan cukup berhasil dalam mengundang simpati masyarakat karena

${ }^{13}$ Lihat, misalnya, kisah-kisah Adam dan pasangannya ini dalam QS. Al-Baqarah (2): 34-38, QS. al-A'raf (7): 11-27 dan QS. Thaha (20): 115-123

${ }^{14} \mathrm{http}: / /$ books.google.co.id/, diakses pada tanggal 14 Juni 2017 pukul 14:00

15 Ibid, hlm. 14 
JURNAL PIWULANG, Vol. I No. 1 September 2018, 1-18

aktivitasnya mengarah kepada peningkatan kecerdasan serta keleluasaan generasi baru yang lebih cakap dan kualitas. ${ }^{16}$

Di antara dalih yang dilontarkan oleh gerakan emansipasi dan karirisasi ini diantaranya:

- Wanita yang tinggal di rumah adalah wanita yang terpasung eksistensinya dan hak hidupnya.

- Tidak menunjang usaha produktivitas masyarakat dan peningkatan pertumbuhan ekonomi negara.

- Dengan hannya sebagai ibu rumah tangga, wanita kehilangan semangat partisipasi dalam setiap derap dan langkah pembangunan bangsa dan negara.

- Wanita yang tinggal di rumah menjadi beban keluarga, baik secara ekonomis maupun moral sehingga hal tersebut menimbulkan kesempatan pada pihak laki-laki untuk melakukan penindasan dan kesewenangan.

c) Wanita Karir

Menurut kamus karier untuk Abad 21 (A Career Lexicon for the 21 Century) yang dikemukakan Arthur dab Rousseau (1996) karier memiliki definis lama dan baru. Penulis artikel tersebut menjelaskan istilah kunci yang terkait dengan dunia karier, yaitu: ${ }^{17}$

1) Karier (career). Dalam Arti lama Karier adalah suatu arah kemajuan profesional; kata yang penggunaannya terbatas pada pekerjaan yang memiliki kemajuan hierarki formal, seperti halnya manajer dan profesional. Sedangkan dalam Arti baru, karir adalah serangkaian pengalaman kerja seseorang yang mengalami perkembangan.

2) Pekerjaan (employment). Dalam arti lama adalah Tindakan mempekerjakan orang atau memanfaatkan sesuatu; keadaan dipekerjakan, pekerjaan atau bisnis reguler seseorang. Sdedangkan dalam arti baru pekerjaan merupakan status sesaat atau manifestasi dari keadaan pekerja yang dipekerjakan untuk waktu lama

Karier merupakan sebuah aktivitas yang digeluti oleh seseorang untuk mengaplikasikan bidang keilmuwan yang ia tekuni dan bakat yang dia miliki serta untuk menghidupi dirinya maupun keluarganya dengan cara bekerja di luar rumah. Karir merupakan pekerjaan yang hanya akan menambah kesulitan bagi

${ }^{16}$ Muhammad Thalib, Solusi Islam Terhadap Dilema Wanita Karir, (Yogyakarta: Wihdah Press, 1999), hlm. 11

17 Muhammad Thalib, Solusi Islam Terhadap Dilema Wanita Karir..., hlm. 11-13 
JURNAL PIWULANG, Vol. I No. 1 September 2018, 1-18

seorang perempuan sehingga mereka tidak dapat melaksanakan tugas domestiknya dengan maksimal. ${ }^{18}$

Islam telah meletakkan syarat-syarat tertentu bagi perempuan yang ingin bekerjadi luar rumah, yaitu: Karena kondisi keluarga yang mendesak, Keluar bersama mahramnya, Tidak berdesak-desakan dengan laki-laki dan bercampur baur dengan mereka. Dan Pekerjaan tersebut sesuai dengan tugas seorang perempuan ${ }^{19}$

d) Pandangan Islam dan Barat Terhadap Wanita Karir

Terhadap persoalan wanita bekerja, ternyata ada dua pandangan berbeda. Kedua pandangan ini telah menjadi referensi dalam menyoroti masalah wanita bekerja. Kedua pandanan yang dimaksud adalah Islam dan Barat.

Dalam perspektif Islam dinyatakan bahwa wanita, baik sebagai anak, istri maupun ibu tidak bertanggung jawab unruk mencari nafkah guna menghidupi dirinya sendiri apalagi menghidupi orang lain. Yang bertanggung jawab memberikan nafkah kepada mereka adalah ayahnya, atau suaminya atau saudara laki-lakinya. Wanita bertugas untuk mengurus kepentingan rumah tangga jika dia telah bersuami dan membantu urusan orang tua (ibunya) di rumah mankala dia masih belum menikah.

Dalam budaya barat, wanita berhak untuk bekerja guna mendapatkan nafkahnya walaupun dia telah bersuami. Akibat prinsip hidup ini membuat wanita terpaksa berpacu dengan lakilaki untuk memperebutkan kesempatan kerja. Dan hal ini membawa konsekuensi ganda bagi wanita apabila dia telah bersuami. Selain bekerja di luar rumah mencari nafkah, dia juga harus mengurus anak-anak dan suaminya di rumah.

\section{Deskripsi Hasil Penelitian}

Wilayah kerja para informan di dalam penelitian ini berada di wilayah kota Malang. Mulai dari rumah informan buruh rokok yang mayoritas berada di Kec.Blimbing. Untuk informan pegawai bank berada di Kec.Klojen, Blimbing dan Lowokwaru. Sedangkan untuk informan guru berada di Kec. Lowokwaru dan Blimbing

Tempat tugas yang menjadi tempat para ibu-ibu yang dijadikan informan pada penelitian ini berkarir adalah lokasi-lokasi yang sesuai

18 Syaikh Mutawalli, Fiqh Perempuan (Muslimah) Busana dan Perhasian, Penghormatan atas Perempuan, Sampai Wanita Karier, (Jakarta: Amzah, 2003), hlm. 141

19 Ibid, hlm. 141 
dengan jenis karir dan masih di terpusat di wilayah kota Malang antara lain :

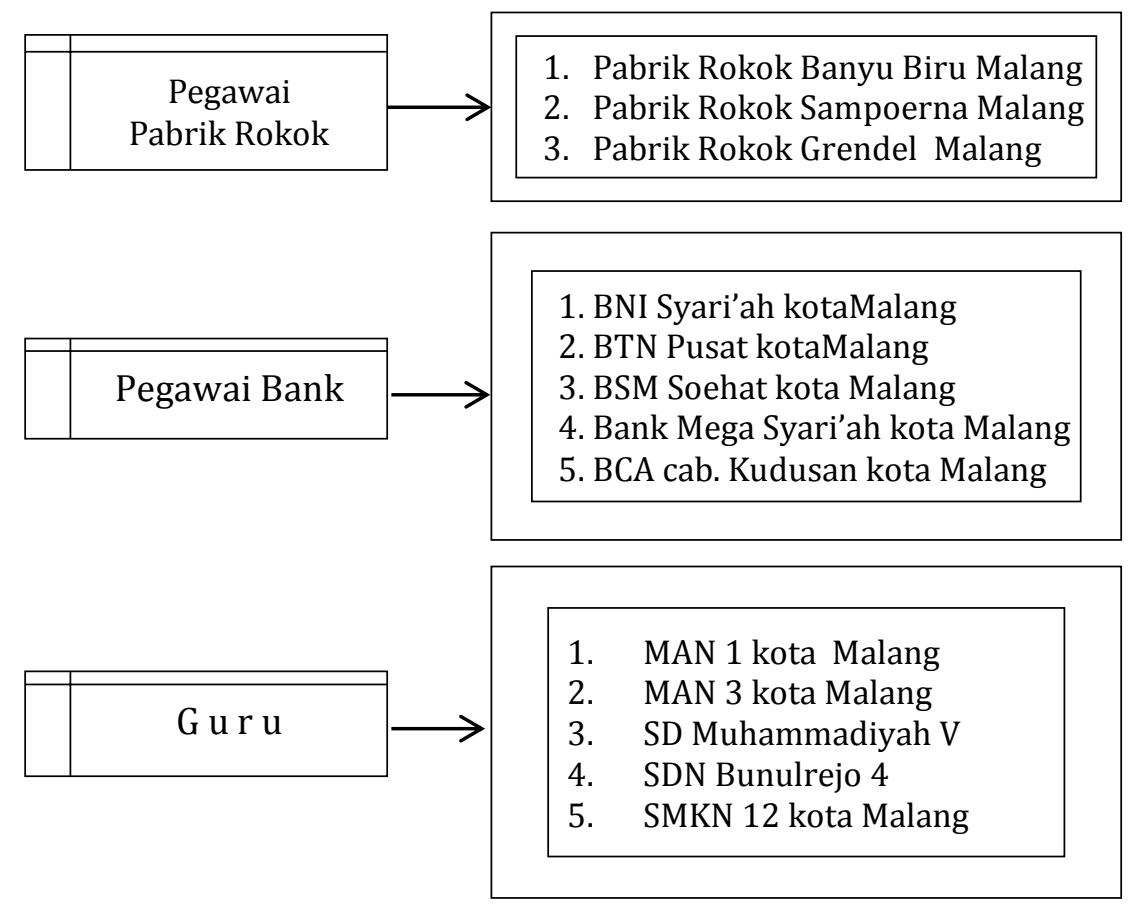

Temuan yang diperoleh dalam aspek cita-cita/ tujuan pendidikan yang ingin dicapai oleh para ibu karir yang menjadi informan mengindikasikan adanya persamaan cita-cita dalam pendidikan anak. Keinginan-keinginan tersebut meliputi (a) keinginan agar putra-putri mereka menjadi anak yang taat beragama, (b) memiliki akhlaq atau tingkah laku yang terpuji baik di dalam rumah, di sekolah dan juga di lingkungan masyarakat, (c) keinginan agar putra-putri mereka menjadi anak yang taat beragama, (d) memiliki akhlaq atau tingkah laku yang terpuji baik di dalam rumah, di sekolah dan juga di lingkungan masyarakat, (e) menginginkan putra-putri mereka menjadi seorang anak yang sholeh dan sholehah serta memiliki keindahan akhlak kepada siapapun, (f) menjadi anak yang tekun beribadah sehingga diharapkan menjadi anak yang bisa meniru atau bahkan melebihi kualitas ibadah Ibu Bapaknya, (g) berbudi luhur yang baik sehingga keberadaannya di masyarakat bisa memberikan kontribusi positif pada nusa, bangs, agama dan juga orang tua.

Ada satu temuan baru terkait upaya penyampaian materi agama pada aspek pendidikan akhlaq ini, yaitu menggunakan metode penempatan anak pada instansi pendidikan yang berciri khas keislaman seperti Playgroup Qurrota A'yun, TK Al-Kautsar, TK Permata Iman dan TK Hidayatul Mubtadi'in. Hal ini merupakan temuan baru yang masih bisa diterima sebagai sebuah tawaran solusi bagi para orang tua yang memiliki 
jam kerja yang sangat padat namun para orang tua tersebut juga tidak ingin mengabaikan pendidikan agama khususnya pada pendidikan akhlaq pada putra-putrinya.

Dengan metode penempatan anak pada instansi pendidikan yang berciri khas keislaman seperti Playgroup Qurrota A'yun, TK Al-Kautsar, TK Permata Iman dan TK Hidayatul Mubtadi'in ini diharapkan anak bisa tumbuh dengan jiwa yang stabil, memiliki pengetahuan umum yang bagus tapi juga memiliki wawasan keilmuwan dalam hal agama yang unggul. Hal ini karena kurikulum yang ada pada instansi pendidikan yang berciri khas keislaman ini menawarkan sebuah solusi bagi seorang anak yang tidak hanya pintar secara intelektual, namun juga berkhlaqul karimah yang mulia.

\section{1) Pendidikan Aqidah}

Dari berbagai pendapat para informan baik dari buruh rokok, pegawai bank dan juga guru mengatakan bahwa pendidikan aqidah bagi anak yang menyangkut pengenalan terhadap Tuhan dan juga terhadap makhluk ghaib bisa melalui berbagai cara, yaitu:

a) Pengenalan sejak memilih calon suami karena agama Islam menganjurkan pada umatnya agar memilih pasangan hidupnya atas dasar agama yang dimiliki.

b) Pengenalan semasa bayi berada di dalam kandungan dengan cara sering membaca ayat suci al-Qur'an sambil minta izin pada si bayi lewat cara mengelus perut si Ibu yang sedang hamil, selalu mendoakan bayi dengan doa-doa yang mulia dan lain sebagainya.

c) Pengenalan pada hal-hal yang bersifat ghaib bisa dengan cara orang tua sering bercerita bahwa di dunia ini terdapat setan yang selalu mengajak para manusia ke arah kemaksiatan dan juga menceritakan bahwa di dalam diri kita terdapat dua Malaikat yang selalu setia mencatat amal baik dan amal buruk manusia.

\section{2) Pendidikan Ibadah}

Dari berbagai pendapat para informan baik dari buruh rokok, pegawai bank dan juga guru mengatakan bahwa pendidikan ibadah bagi anak yang menyangkut pengenalan terhadap pentingnya ibadah, pelaksanaan ibadah, pembiasaan ibadah dan pengawasan terhadap ibadah anak bisa melalui berbagai cara, yaitu:

a) Pengenalan terhadap pentingnya beribadah lewat cara pengajaran langsung dari orang tua. Bisa juga dengan cara langsung mengajak anak untuk mempraktekkan bersama-sama ibadah yang sesuai dengan kemampuan anak, misalnya: pada umur 3 tahun ketika anak bisa merespon perkataan orang tua, maka orang tua mengajak anak untuk sholat berjamaah di mesjid meskipun pada kenyataannya 
tidak sedikit para anak-anak tersebut mengganggu aktivitas ibadah orang tuanya.

b) Pengenalan terhadap pentingnya beribadah bisa juga dengan cara menjadikan sosok orang tua sebagai contoh yang baik bagi anak dalam hal beribadah karena pada hakikatnya anak akan meniru prilaku keseharian orang tuanya termasuk dalam hal beribadah.

c) Bagi para orang tua yang amat sibuk dengan karirnya seperti beberapa informan yang bekerja sebagai pegawai bank, maka mereka memasrahkan pendidikan ibadah anak pada instansi pendidikan formal yang bernafaskan Islam seperti: Playgroup Qurrota A'yun, TK Al-Kautsar, TK Permata Iman dan TK Hidayatul Mubtadi'in.

d) Pelaksanaan ibadah misalnya shalat dan puasa pada jawaban beberapa informan memiliki perbedaan yang tidak jauh. Contohnya saja ada ibu yang bekerja di Pabrik Rokok mulai menyuruh anaknya untuk memulai shalat pada saat anak masuk SD sekitar umur 6 tahun. Lain lagi dengan jawaban dari seorang ibu yang bekerja sebagai Pegawai Bank yang mulai mengajak dan menyuruh anakanaknya untuk belajar melaksanakan shalat atau puasa pada usia 3 tahun dimana pada saat tersebut anak sudah dapat merespon perkataan ibunya dan juga meniru prilaku keseharian Ibunya termasuk prilaku beribadah. Sedangkan salah satu jawaban dari seseorang yang bekerja sebagai guru mulai mengajak putraputrinya untuk beribadah ketika anak mulai masuk TK sekitar usia $4-4,5$ tahun.

e) Pembiasaan prilaku beribadah anak menuntut peran aktif orang tua dalam melakukan pendampingan karena pada usia anak yang relatif masih dalam tahap kanak-kanak sampai dengan tahap anak yang berada pada usia 2-6 tahun membutuhkan pendampingan dan pengawasan langsung dari orang tua. Hal ini disebabkan karena pada usia tersebut seorang anak masih belum bisa melaksanakan $100 \%$ ibadah yang telah diajarkan oleh orang tua. Penyebabnya adalah kadang anak masih seringlupa jika waktu shalat telah tiba karena terlalu lama bermain di luar rumah, terkadang anak susah untuk bangun di waktu subuh dan terkadang pula anak telah tertidur sebelum anak tersebut menunaikan ibadah shalat isya'.

\section{3) Pendidikan Akhlaq}

Dari berbagai pendapat para informan baik dari buruh rokok, pegawai bank dan juga guru mengatakan bahwa pendidikan akhlaq bagi anak yang menyangkut pengenalan terhadap akhlaq bisa melalui berbagai cara, yaitu: 
JURNAL PIWULANG, Vol. I No. 1 September 2018, 1-18

a) Pengenalan terhadap pentingnya akhlaq terpuji dan akhlaq tercela bisa dengan cara menjadikan sosok orang tua sebagai contoh yang baik (uswatun hasanah) bagi anak dalam hal berakhlaq karena pada hakikatnya anak akan meniru prilaku keseharian orang tuanya termasuk dalam hal berkhlaq terpuji dan tercela.

b. Pengajaran langsung dari orang tua dengan cara langsung menceritakan kisah-kisah yang ada kaitannya dengan prilaku berakhlaq terpuji dan prilaku berakhlaq tercela yang ada dalam kehidupan sehari-hari.

c. Metode pemberian hadiah (reward) dan hukuman (punishment) kepada anak dalam kaitannya dengan akhlaq terpuji maupun akhlaq tercela yang dilakukan oleh anak.

d. Bagi para orang tua yang amat sibuk dengan karirnya seperti beberapa informan yang bekerja sebagai pegawai bank, maka mereka memasrahkan pendidikan akhlaq anak pada instansi pendidikan formal yang bernafaskan Islam seperti: Playgroup Qurrota A'yun, TK Al-Kautsar, TK Permata Iman, TK Hidayatul Mubtadi'in, MIN, MTsN 1 dan MAN 1 Malang.

\begin{tabular}{|c|c|c|c|c|}
\hline No & $\begin{array}{l}\text { Jenis } \\
\text { Karir }\end{array}$ & $\begin{array}{c}\text { Jenis } \\
\text { Pendidikan }\end{array}$ & Metode & Temuan \\
\hline 1. & $\begin{array}{l}\text { Buruh } \\
\text { Rokok }\end{array}$ & $\begin{array}{l}\text { - Pendidikan } \\
\text { Aqidah } \\
\text { - Pendidikan } \\
\text { Ibadah } \\
\\
\text { - Pendidikan } \\
\text { Akhlaq }\end{array}$ & $\begin{aligned}> & \text { Direcitive Learning } \\
> & \text { Directive Learning } \\
> & \text { Reward and } \\
& \text { Punishment } \\
> & \text { Pemberian Contoh } \\
> & \text { Directive Learning } \\
> & \text { Reward and } \\
& \text { Punishment } \\
> & \text { Pemberian Contoh }\end{aligned}$ & * TPQ/ Guru Ngaji \\
\hline 2 & $\begin{array}{l}\text { Pegawai } \\
\text { Bank }\end{array}$ & $\begin{array}{l}\text { - Pendidikan } \\
\text { Aqidah } \\
\text { - Pendidikan } \\
\text { Ibadah } \\
\\
\text { - Pendidikan } \\
\text { Akhlaq }\end{array}$ & $\begin{array}{l}>\text { Direcitive Learning } \\
>\text { Directive Learning } \\
>\text { Reward and } \\
\text { Punishment } \\
>\text { Pemberian Contoh } \\
>\text { Directive Learning } \\
>\text { Reward and } \\
\end{array}$ & $\begin{array}{l}\text { - } \\
\text { Anak disekolahkan } \\
\text { pada instansi } \\
\text { pendidikan yang } \\
\text { menawarkan porsi } \\
\text { lebih pada hal yang } \\
\text { bersifat keagamaan, } \\
\text { seperti: Playgroup } \\
\text { Qurrota A'yun, TK Al- } \\
\text { Kautsar, TK Permata } \\
\text { Iman, TK Hidayatul } \\
\text { Mubtadi'in, MIN } 1 \\
\text { Malang dll. } \\
\text { Anak dimasukkan pada } \\
\text { lembaga pendidikan }\end{array}$ \\
\hline
\end{tabular}


JURNAL PIWULANG, Vol. I No. 1 September 2018, 1-18

\begin{tabular}{|c|c|c|c|c|c|}
\hline & & & & $\begin{array}{l}\text { Punishment } \\
\text { Pemberian Contoh }\end{array}$ & $\begin{array}{l}\text { yang menawarkan } \\
\text { porsi lebih pada hal } \\
\text { yang bersifat } \\
\text { keagamaan, seperti: } \\
\text { Playgroup Qurrota } \\
\text { A'yun, TK Al-Kautsar, } \\
\text { TK Permata Iman, TK } \\
\text { Hidayatul Mubtadi'in, } \\
\text { MIN } 1 \text { Malang dll }\end{array}$ \\
\hline \multirow[t]{3}{*}{3} & \multirow[t]{3}{*}{ Guru } & $\begin{array}{l}\text { - Pendidikan } \\
\text { Aqidah }\end{array}$ & $>$ & Directive Learning & $\begin{array}{l}\text { TPQ/ Guru Ngaji } \\
\text { Anak disekolahkan } \\
\text { pada instansi } \\
\text { pendidikan yang } \\
\text { menawarkan porsi } \\
\text { lebih pada hal yang } \\
\text { bersifat keagamaan, } \\
\text { seperti: TK } \\
\text { Muslimat, MI } \\
\text { Muslimat, MIN } 1 \\
\text { Malang, MTsN } 1 \\
\text { Malang, MAN } 3 \\
\text { Malang dan UIN } \\
\text { Maliki Malang }\end{array}$ \\
\hline & & $\begin{array}{l}\text { - Pendidikan } \\
\text { Ibadah }\end{array}$ & & $\begin{array}{l}\text { Directive Learning } \\
\text { Reward and } \\
\text { Punishment } \\
\text { Pemberian Contoh }\end{array}$ & Idiom \\
\hline & & $\begin{array}{l}\text { - Pendidikan } \\
\text { Akhlaq }\end{array}$ & & $\begin{array}{l}\text { Directive Learning } \\
\text { Reward and } \\
\text { Punishment } \\
\text { Pemberian Contoh }\end{array}$ & Idiom \\
\hline
\end{tabular}

Keberhasilan atas upaya yang dilakukan oleh para orang tua menunjukkan sebuah realita beragam, mulai dari (a) memiliki anak yang di usia 6 tahun anak sudah terbiasa sholat 5 waktu, (b) sudah terbiasa mengucapkan salam ketika keluar masuk rumah, (c) memiliki anak pertama sampai anak ketiga selalu menunjukkan akhlaq yang santun kepada orang tua dari sejak kecil sampai saat ini meski ketiga-tiganya saat ini telah berkeluarga, (d) memiliki anak laki-laki sudah terbiasa pergi ke mesjid untuk sholat maghrib dan subuh berjama'ah, (e) memiliki anak yang sudah terbiasa berkhlaq baik terhadap orang tua sejak kecil, (f) anak juga sudah pandai mengaji serta sholat lima waktu, (g) memiliki anak yang sudah terbiasa menawarkan minuman ketika menyambut kedua orang tua yang pulang dari bekerja, (h) memiliki anak selalu mengawali sesuatu dengan bacaaan basmalah, (i) memiliki anak yang selalu membiasakan berdo'a setiap akan melakukan sesuatu, misalnya ketika mau makan, 
JURNAL PIWULANG, Vol. I No. 1 September 2018, 1-18

bepergian ataupun akan tidur (j) memiliki anak yang membiasakan dirinya masing-masing membaca al-quran setelah sholat maghrib dan subuh.

\section{Penutup}

Ada beberapa Model Pendidikan Agama Islam Ibu Karir Pada Anak Dalam Keluarga Muslim, di antaranyab dalam Pendidikan aqidah lebih condong pada metode Directive Learning. Hal ini bisa dibuktikan dengan jawaban dari para informan dari yang bekerja sebagai buruh rokok, pegawai bank dan juga guru memiliki kesamaan jawaban yaitu menggunakan metode pengajaran langsung (Directive Learning) tentang sebuah materi aqidah dari orang tua kepada putra-putrinya. Pendidikan ibadah lebih condong pada dua metode yaitu metode Directive Learning dan metode Pemberian Contoh. Hal ini dapat kita lihat pada jawaban para informan baik yang bekerja sebagai buruh rokok, pegawai bank dan juga guru memiliki kesamaan jawaban yaitu menggunakan metode Directive Learning dan metode Pemberian Contoh.

Pada Pendidikan akhlaq banyak mengarah pada dua metode yaitu metode Directive Learning dan metode Pemberian Contoh. Hal ini dapat kita lihat pada jawaban para informan baik yang bekerja sebagai buruh rokok, pegawai bank dan juga guru memiliki kesamaan jawaban yaitu menggunakan model Directive Learning dan model Pemberian Contoh dalam hal melakukan penengalan dan pengajaran akhlaq pada putraputrinya.

Dalam kaitannya dengan metode penyampaian materi agama pada aspek pendidikan aqidah, ibadah dan akhlaq, yaitu model penempatan anak pada instansi pendidikan yang berciri khas keislaman seperti Playgroup Qurrota A'yun, TK Al-Kautsar, TK Permata Iman dan TK Hidayatul Mubtadi'in. Hal ini merupakan sebagai salah satu solusi bagi para orang tua yang memiliki jam kerja yang sangat padat namun para orang tua tersebut juga tidak ingin mengabaikan pendidikan agama khususnya pada pendidikan akhlaq pada putra-putrinya. Namun setiap metode pengajaran pendidikan agama Islam pasti memiliki kelebihan dan kelemahan masing-masing. Jadi, disinilah tuntutan pada setiap orang tua agar mereka lebih arif dan bijaksana dalam menerapkan sebuah metode pengajaran materi pendidikan agama Islam bagi anak di rumah.

\section{Daftar Rujukan}

Ch, Mufidah. 2003. Paradigma Gender, (Malang: Bayumedia Publishing)

Indrakusuma, Amir. Daien 1973. Pengantar Ilmu Pendidikan, (Surabaya: Usaha Offset Printing)

Kartono, Kartini. 2007. Psikologi Anak (Psikologi Perkembangan). (Bandung: Mandar Maju) 
JURNAL PIWULANG, Vol. I No. 1 September 2018, 1-18

Koentjaraningrat. 1997. Metode-metode Penelitian Masyarakat. (Jakarta: PT Gramedia Pustaka Utama)

Mutawalli, Syaikh. 2003. Fiqh Perempuan (Muslimah) Busana dan Perhasian, Penghormatan atas Perempuan, Sampai Wanita Karier. (Jakarta: Amzah)

Nazarudin. 2007. Manajemen Pembelajaran Implementasi Konsep, Karakteristik dan Metodologi Pendidikan Agama Islam di Sekolah Umum, (Yogyakarta: Teras)

Nuryanis, dkk. 2003. Pendidikan Luar Sekolah, Kontribusi Ditpenamas Dalam Pencapaian Tujuan Pendidikan Nasional, (Jakarta: Depag RI Dirjen Kelembagaan Agama Islam)

Padil, Moh. dkk. 2007. Sosiologi Pendidikan. (Malang: UIN-Malang Press)

Patmonodewo, Soemiarti. 2000. Pendidikan Anak Prasekolah, (Jakarta: Rineka Cipta)

Rimm, Sylvia. 2003. Mendidik dan Menerapkan Disiplin Pada Anak Prasekolah, (Jakarta, PT Gramedia Pustaka Utama)

Seto, Kak. 2000. Pendidikan dan Masalah Perkembangan Anak, Dalam Sindhunata (Ed.), Membuka Masa Depan Anak-Anak Kita: Mencari Kurikulum Pendidikan Abad XXI, (Yogyakarta: Kanisius)

Schaefer, Charles. 1989. Bagaiman Mempengaruhi Anak Peganagan Praktis Bagi Orang Tua, (Semarang: Dahara Prize)

Thalib, Muhammad. 1999. Solusi Islam Terhadap Dilema Wanita Karir, (Yogyakarta: Wihdah Press)

Ulwan, Abdullah Nashih. 1992. Pendidikan Anak Menurut Islam Kaidah-Kaidah Dasar, (Bandung: PT Remaja Rosdakarya)

1983. Pusat Pengembangan Penataran Guru Tertulis Ditjen Dikdasmen Depdikbud, Bimbingan dan Penyuluhan. Bandung

www.najmulhayah's.blog.com, diakses pada tanggal 25-02-2012 pukul 10.00 WIB

www.arisandi.com, diakses pada tanggal 25-02-2012 pukul 09.58 WIB

http://books.google.co.id/, diakses pada tanggal 14 April 2011 pukul 14:00 